\title{
Occurrence and risk characterization of polycyclic aromatic hydrocarbons of edible oils by the Margin of Exposure (MOE) approach
}

Joon-Goo Lee, Jung-Hyuck Suh and Hae-Jung Yoon*

\begin{abstract}
Polycyclic aromatic hydrocarbons (PAHs) are carcinogenic and genotoxic chemicals naturally derived from food during heat processing. Edible oil is one of the most frequently contaminated foods. Many researches were recently conducted to determine the contents of PAHs and to assess their risks, but there have been no studies characterising risks of PAHs by calculating Margin of Exposure (MOE) of total PAHs instead of toxic equivalency factors (TEFs) concept in Korea. To analyze the 4 PAHs including benz(a)anthracene (BaA), chrysene (CHR), benzo(b)fluoranthene (BbF), and benzo(a)pyrene (BaP) simultaneously, gas chromatography with mass spectrometry was optimized. Total 303 edible oils were investigated and contaminated by 4 PAHs at ND-12.91 $\mathrm{ng} \mathrm{g}^{-1}$. The MOEs were estimated by PAHs contents, daily consumption, and were over 10,000. The risk of PAHs of edible oils in Korea was of low concern. Furthermore, the MOEs of the estimated equivalent BaP calculated by TEFs of other 3 PAHs were higher than those of mixed PAHs, which would be overestimated.
\end{abstract}

Keywords: Polycyclic aromatic hydrocarbons, Edible oil, Exposure assessment, Risk characterization, Toxic equivalency quotient

\section{Introduction}

Polycyclic aromatic hydrocarbons (PAHs) are organic compounds consisting of two or more fused benzene rings [1]. They are produced from the incomplete combustion of organic matter and geochemical process. Some PAHs have been proven to be carcinogenic and genotoxic compounds as they bind to DNA [1]. Sixteen PAHs are actually classified as priority pollutants by Environmental Protection Agency (EPA) on the basis of their occurrence and carcinogenicity [2]. The European Union had set maximum levels for benzo(a)pyrene (BaP) as an indicator for general PAHs in foods. However, European Food Safety Authority (EFSA) recently concluded that BaP is not suitable as marker for the PAHs, and PAH4 including benz(a)anthracene $(\mathrm{BaA})$, chrysene (CHR), benzo(b)

\footnotetext{
*Correspondence: hjyoon@korea.kr

Food Contaminants Division, Department of Food Safety Evaluation, National Institute of Food and Drug Safety Evaluation, Ministry of Food and Drug Safety, Osong-eup, Cheongwon-gun, Cheongju-si, Chungcheongbuk-do 363-700, South Korea
}

fluoranthene $(\mathrm{BbF})$, and benzo(a)pyrene $(\mathrm{BaP})$ would be proper as indicators [3]. The European Union added new maximum levels for sum of PAH4 in foods [4].

The occurrence of PAHs in food is due to environmental contamination, manufacturing and cooking process, and occasionally PAHs appear in low amount from contaminated packaging material [5-7]. Some research has been conducted to investigate PAHs in food samples and much information of contamination to PAHs in various food stuffs have been published [3, 8]. Fats and oils are particularly prone to PAHs contamination because of their strong lipophilic characteristics [9]. Various routes of PAHs contamination in vegetable oils also have been suggested. The seed drying process using direct firing for production of hot air can be responsible for major PAHs contamination of some vegetable oils. Another possibility of PAHs contamination in vegetable oil may be carried over from contaminated soil, water, air or packaging materials [10]. The direct consumption or usage of fats and oils as an ingredient in foods is one of the most important reasons that PAHs in oil should be considered [11, 12]. 
Furthermore, the strong intestinal absorption of PAHs in fats and oils is another important reason for the PAHs in fats and oils to be considered important concerns [13]. However, crude edible oil is refined and dewaxed through purification process. The PAHs levels can be drastically reduced by refining with the final level depending on the refining conditions [10]. Therefore, the control of pressed oil without refining process is more important than refined oils. Several researches estimated the exposure to PAHs by consuming edible oils, since US EPA adopted relevance of the toxic equivalency quotient (TEQ) concept to estimate of exposure to PAHs [15]. BaP equivalent concentrations $\left(\mathrm{TEQ}_{\mathrm{BaP}}\right)$ were produced by multiplying each PAH concentration with its toxic equivalency factors (TEFs) [15-17]. However, EFSA recently concluded that the TEQ approach is only suitable for the compounds which have the same mechanism of toxicological effect such as polychlorinated dibenzo- $p$-dioxins and -dibenzofurans. Although a number of PAHs have the same effect showing the carcinogenic potency of PAHs by binding to DNA and inducing a mutation, PAHs also produce tumors in other mechanisms [3]. Therefore, a toxicological value calculated from mixture of PAHs should be used to assess the risk of PAHs. However, there have been no researches that assess the risk of PAHs using new toxicological value, not a TEQ approachedvalue. To assess a risk of PAHs to the public health by consuming edible oils, Margin of Exposures (MOEs) based on the benchmark dose lower confidence limit for a $10 \%$ increase in the number of tumour-bearing animals compared to control animals $\left(\mathrm{BMDL}_{10}\right)$ have been used [18, 19]. Substances which are genotoxic and carcinogenic may show the limit of detection in dose-response relationship of a bioassay, rather than an estimate of a possible threshold, and a health-based reference value could not be set [18]. Therefore, it has been recommended to reduce them to As Low As Reasonably Achievable (ALARA) amount [20]. The MOE has become the preferred option and has been used for providing a risk priority to risk managers [21]. The objectives of this study were to evaluate PAHs contaminations including $\mathrm{BaA}, \mathrm{CHR}, \mathrm{BbF}$, and $\mathrm{BaP}$ in edible oils in the Korean market and to assess a risk to the public health by consuming edible oils with MOE. Furthermore, the researchers also compared the risks estimated from new toxicological values and traditional toxic equivalency factor (TEF) values.

\section{Experimental procedures \\ Chemicals and materials}

The standards of PAH4; $\mathrm{BaA}, \mathrm{CHR}, \mathrm{BbF}, \mathrm{BaP}$ and 2 deuterated internal standards; and CHR-d12 and BaPd12 were obtained from Supelco (Bellefonte, PA, USA). The 4 standards and 2 internal standards were separately dissolved in dichloromethane to make stocking standard of $100 \mu \mathrm{g} \mathrm{mL} \mathrm{mL}^{-1}$ and stored in ambient storage at $-25{ }^{\circ} \mathrm{C}$. Working standards $\left(1-500 \mu \mathrm{g} \mathrm{L}{ }^{-1}\right)$ were prepared by diluting stocking standard with dichloromethane, and stored at $4{ }^{\circ} \mathrm{C}$. HPLC grade of $N, N$ dimethylformamide(DMF), ethylacetate, and $n$-hexane from Merck (Darmstadt, Germany), and HPLC grade of dichloromethane from Burdick \& Jackson (Muskegon, MI, USA) were prepared. Distilled Water (DW) was made by purifying tap water with a Milli-Q System (Millipore, Bedford, MA, USA). Sodium sulfate was obtained from Wako (Osaka, Japan). Sep-pak ${ }^{\circledR}$ Vac (1 g/6 cc) with silica resin of Waters Corporation (Milford, MA, USA) and SupelMIP ${ }^{\circledR}$ SPE-PAHs $(50 \mathrm{mg} / 3 \mathrm{cc})$ of Supelco (Bellefonte, PA, USA) were purchased as SPE cartridge.

\section{Sample preperation}

We chose edible oils to analyse and assess the risk according to the consumption data from the Korea National Health and Nutrition Examination Survey (KNHANES) and the procedure to extract oils. Sesame oils, perilla oils and olive oils were selected because they are the most consumed oils in Korea by the KNHANES. There are no consuming data for other edible oils in the KNHANES. And red pepper oils and red pepper seasoning oils were also selected because they were extracted followed by frying seeds with high temperature, which can produce PAHs easily [22-24]. In total, 303 edible oils including 129 sesame oils, 71 perilla oils, 16 pepper seeds oils, 53 olive oils and 34 red pepper seasoning oils were purchased at Korean offline markets relative to population by region and online markets in 2013. All sesame oils and perilla oils are extracted on markets by ourselves with Korean sesame seeds and perilla seeds. Others are purchased on markets which were already extracted by stores. Samples were stored in the darkness in near-full bottles at blow of $20^{\circ} \mathrm{C}$.

\section{Pretreatment of sample}

A sample of $10 \mathrm{~g}$ was weighed and moved into a separatory funnel, and then it was shaken with $N, N$-DMF-DW $(9: 1, \mathrm{v} / \mathrm{v})$ of $50 \mathrm{~mL}$ and $n$-hexane of $100 \mathrm{~mL}$ in the presence of the 2 deuterated internal standards $\left(4 \mathrm{ng} \mathrm{g}^{-1}\right)$. The $N, N-D M F-D W(9: 1, \mathrm{v} / \mathrm{v})$ was moved to an another separatory funnel and hexane layer solution extracted twice with $25 \mathrm{~mL}$ of $N, N$-DMF-DW $(9: 1, \mathrm{v} / \mathrm{v})$ by shaking and equilibrating it. A sodium sulfate solution (1\%) of $100 \mathrm{~mL}$ aliquot and $n$-hexane of $50 \mathrm{~mL}$ were added to the $N, N$ DMF-DW layer and shaken, and the $n$-hexane layer was transferred to another separatory funnel. The extraction with $n$-hexane was repeated twice. The extracted hexane were washed with $40 \mathrm{~mL}$ of DW 3 times, and then, anhydrous $\mathrm{Na}_{2} \mathrm{SO}_{4}(15 \mathrm{~g})$ was added to the hexane extract to remove DW remained. The extract was evaporated to 
approximately $2 \mathrm{~mL}$ by a rotary evaporator (Eyela, Tokyo Rikakikai Co. Ltd., Japan) to be purified with SPE catrideges [25]. The condensed extract was firstly purified with the silica cartridge activated with dichloromethane $(10 \mathrm{~mL})$ and $n$-hexane $(20 \mathrm{~mL})$, and then the cartridge was washed with $n$-hexane $(5 \mathrm{~mL})$ and eluted with $n$-hexane-dichloromethane $(3: 1, \mathrm{v} / \mathrm{v})(15 \mathrm{~mL})$. The eluate was concentrated to approximately $2 \mathrm{~mL}$ using a rotary evaporator. The concentrate was purified by passing through a SPE-PAHs cartridge previously activated with $n$-hexane $(1 \mathrm{~mL})$, and the cartridge was eluted with $0.5 \mathrm{~mL}$ and $1 \mathrm{~mL}$ of $n$-hexane followed by $3 \mathrm{~mL}$ of ethylacetate. The eluate was dried with a nitrogen evaporator (Oa-SYS Heating Device 5085, Organomation Associates. Inc., USA) at 20 psi stream of nitrogen $\left(40{ }^{\circ} \mathrm{C}\right)$. The analyte was finally prepared by dissolving the dryness in $200 \mu \mathrm{L}$ of dichloromethane for GC-MS analysis.

\section{GC-MS analysis of PAHs}

Determination of PAHs was conducted using a GC apparatus (Agilent Technology 7890A, USA) with a mass spectrometer (Agilent Technology 5975C, USA). GC was equipped with a DB-5 ms Column (30 m length $\times 0.25 \mathrm{~mm}$ inner diameter $\times 0.25 \mu \mathrm{m}$ film thickness, Agilent Technology, USA), and the oven initially prepared at $80^{\circ} \mathrm{C}$ for $1 \mathrm{~min}$ was heated to $245^{\circ} \mathrm{C}$ at a rate of $4{ }^{\circ} \mathrm{C} \mathrm{min}{ }^{-1}$. And then, the temperature of oven was ramped up to $270{ }^{\circ} \mathrm{C}$ at a rate of $30^{\circ} \mathrm{C} \mathrm{min}^{-1}$ and finally held for $10 \mathrm{~min}$. Helium was flown at $1.5 \mathrm{~mL} \mathrm{~min}{ }^{-1}$ as carrier gas. The injector temperature and injection volume were $320^{\circ} \mathrm{C}$ and $1 \mu \mathrm{L}$, respectively. The analyte was injected to GC-MS with a splitless mode. Temperature of MS source was $250{ }^{\circ} \mathrm{C}$ and spectrometry of MS was obtained by using selective ion monitoring (SIM) modes with the electron ionization (EI) at $70 \mathrm{eV}$. The $\mathrm{BaA}$ and $\mathrm{CHR}$ ions were $\mathrm{m} / \mathrm{z} 228, \mathrm{~m} / \mathrm{z} 229, \mathrm{~m} / \mathrm{z} \mathrm{226}$, and the quantitative analysis target ion was $\mathrm{m} / \mathrm{z} 228 . \mathrm{BbF}$ and $\mathrm{BaP}$ were $\mathrm{m} / \mathrm{z} 252, \mathrm{~m} / \mathrm{z} 253, \mathrm{~m} / \mathrm{z} 250$, and the quantitative analysis target ion was $\mathrm{m} / \mathrm{z} 252$. CHR-d 12 was $\mathrm{m} / \mathrm{z}$ $240, \mathrm{~m} / \mathrm{z} 241, \mathrm{~m} / \mathrm{z} 236$, and the quantitative analysis target ion was $\mathrm{m} / \mathrm{z} 240$. BaP-d12 was $\mathrm{m} / \mathrm{z} 264, \mathrm{~m} / \mathrm{z} 265, \mathrm{~m} / \mathrm{z}$ 260 , and the quantitative analysis target ion was $\mathrm{m} / \mathrm{z} 264$. When the difference of the ratios of other two qualifying ions in sample and standard were within $10 \%$, the peaks of PAHs in sample were accepted [25].

\section{Analytical quality control}

The method was validated to ensure the quality of analytical results. Performance parameters: specificity, limit of detection (LOD), limit of quantification (LOQ), linearity, recovery, and precision were obtained to validate the method based on guidelines recommended by the International research group [26]. Specificity was obtained by checking the isolation of PAHs peaks from noise peaks in samples fortified with PAHs. LOD was statistically estimated by multiplying 3 to a standard deviation obtained in repeated analysis of the lowest control 7 samples of $1.0 \mathrm{ng} \mathrm{g}^{-1}$. LOQ was calculated by multiplying 9 to the same standard deviation. Linearity of calibration curve was evaluated by calculating the correlation coefficient $\left(R^{2}\right)$. Six working standards of 1.0, 5.0, 10.0, 50.0, 100.0 and $500.0 \mu \mathrm{g} \mathrm{L}^{-1}$ were plotted and calibration curve was obtained by regressing an equation of 6 plots. The relative recovery of accuracy was obtained by analyzing five samples fortified with standards of $2.0 \mathrm{ng} \mathrm{g}^{-1}$ and $10 \mathrm{ng} \mathrm{g}^{-1}$ and deuterated internal standards of $4.0 \mathrm{ng} \mathrm{g}^{-1}$ and calculating the average percentage of determined concentration via fortified amount. The repeatability of accuracy was evaluated by calculating the relative standard deviation $\left(\mathrm{RSD}^{\mathrm{r}}\right)$ obtained in the recovery experiments. The reproducibility of accuracy was evaluated by calculating the relative standard deviation $\left(\mathrm{RSD}^{\mathrm{R}}\right)$ in experiments conducted by 4 different labs.

\section{Exposure estimation and risk characterisation}

Exposure to PAHs was estimated by combining PAHs contamination levels and edible oil consuming amounts. PAHs concentration and edible oil consuming data were obtained by this study and KNHANES, respectively. Consumption data of edible oils for total population and consumers were originated from KNHANES IV and V. KNHANES IV was conducted from 2007 to 2009 and KNHANES V was carried out from 2010 to 2012. The second and third programmes of KNHANES IV in 2008 and 2009 and the first programme of KNHANES V in 2010 were selected to assess exposure to edible oils. The numbers of samples in 2008, 2009 and 2010 were 9308, 10,078 and 8473 , respectively [22-24]. The KNHANES is composed of three surveys: health interview, health examination and nutrition survey and food consumption data is collected by nutrition survey. Nutrition survey is conducted by face to face interview in sample person's home using the $24 \mathrm{~h}$ recall method [27].

The values below LOD were statistically assumed based on the recommendation of GEMS/Food. When the proportion of data below LOD was zero, the concentration of PAHs was not statistically modified. Meanwhile, when the proportion was between 60 and $80 \%$ and more than 25 samples were detected, or when the proportion of notdetected samples was higher than $80 \%$, the PAHs concentration was assumed to zero for lower-bound (LB) and to value of LOD for upper-bound (UB). When not-detected sample was between $0 \%$ and $60 \%$, the concentration of PAHs was replaced to half of LOD value [28]. To calculate total PAHs concentration, the concentrations of each PAH were combined to use new toxicological 
Table 1 Performance parameters of the method in optimum condition

\begin{tabular}{|c|c|c|c|c|c|c|c|c|c|}
\hline \multirow[t]{2}{*}{ Oil type } & \multirow[t]{2}{*}{ PAHs } & \multirow[t]{2}{*}{$\operatorname{LOD}\left(\mathrm{ng} \mathrm{g}^{-1}\right)$} & \multirow[t]{2}{*}{$\operatorname{LOQ}\left(\mathrm{ng} \mathrm{g}^{-1}\right)$} & \multicolumn{2}{|l|}{ Recovery } & \multicolumn{2}{|l|}{$\mathrm{RSD}^{\mathrm{r}}(\%)$} & \multicolumn{2}{|l|}{$\mathrm{RSD}^{\mathrm{R}}(\%)$} \\
\hline & & & & $2 \mathrm{ng} \mathrm{g}^{-1}$ & $10 \mathrm{ng} \mathrm{g}^{-1}$ & $2 \mathrm{ng} \mathrm{g}^{-1}$ & $10 \mathrm{ng} \mathrm{g}^{-1}$ & $2 \mathrm{ng} \mathrm{g}^{-1}$ & $10 \mathrm{ng} \mathrm{g}^{-1}$ \\
\hline \multirow[t]{4}{*}{ Sesame oil } & $\mathrm{BaA}$ & 0.04 & 0.14 & 87.0 & $112 . .6$ & 5.4 & 4.9 & 9.8 & 6.9 \\
\hline & $\mathrm{CHR}$ & 0.05 & 0.18 & 93.1 & 103.6 & 3.3 & 5.8 & 17.2 & 5.5 \\
\hline & $\mathrm{BbF}$ & 0.04 & 0.14 & 79.0 & 96.9 & 3.1 & 2.6 & 9.6 & 9.8 \\
\hline & $\mathrm{BaP}$ & 0.02 & 0.08 & 78.3 & 99.5 & 0.3 & 2.0 & 5.5 & 8.9 \\
\hline \multirow[t]{4}{*}{ Perilla oil } & $\mathrm{BaA}$ & 0.08 & 0.26 & 106.6 & 94.5 & 5.3 & 5.9 & 4.9 & 3.9 \\
\hline & $\mathrm{CHR}$ & 0.05 & 0.16 & 99.1 & 96.5 & 3.0 & 7.1 & 7.7 & 0.9 \\
\hline & $\mathrm{BbF}$ & 0.08 & 0.25 & 70.7 & 95.9 & 1.1 & 3.0 & 12.0 & 9.8 \\
\hline & $\mathrm{BaP}$ & 0.07 & 0.23 & 83.4 & 100.5 & 0.3 & 6.1 & 7.4 & 8.1 \\
\hline \multirow[t]{4}{*}{ Pepper seeds oil } & $\mathrm{BaA}$ & 0.09 & 0.30 & 107.7 & 112.1 & 3.2 & 1.7 & 9.7 & 8.9 \\
\hline & $\mathrm{CHR}$ & 0.13 & 0.44 & 100.5 & 112.6 & 2.4 & 3.0 & 2.1 & 9.4 \\
\hline & $\mathrm{BbF}$ & 0.02 & 0.06 & 73.5 & 99.7 & 2.2 & 2.6 & 11.5 & 8.4 \\
\hline & $\mathrm{BaP}$ & 0.02 & 0.06 & 87.6 & 111.6 & 1.3 & 5.4 & 4.7 & 12.5 \\
\hline \multirow[t]{4}{*}{ Olive oil } & $\mathrm{BaA}$ & 0.04 & 0.12 & 110.4 & 79.9 & 5.0 & 8.0 & 6.9 & 10.3 \\
\hline & $\mathrm{CHR}$ & 0.10 & 0.32 & 97.0 & 94.5 & 6.9 & 1.4 & 7.7 & 6.7 \\
\hline & $\mathrm{BbF}$ & 0.03 & 0.11 & 71.4 & 90.2 & 1.3 & 8.8 & 14.4 & 12.7 \\
\hline & $\mathrm{BaP}$ & 0.02 & 0.08 & 83.0 & 84.9 & 1.3 & 1.9 & 6.2 & 5.3 \\
\hline
\end{tabular}

$L O D$ limit of detection, $L O Q$ limit of quantification, $R S D^{r}$ relative standard deviation of repeatability in single-lab, $R S D^{R}$ relative standard deviation of reproducibility in multi-lab

values. Meanwhile, to use TEQ concept, $\mathrm{BaA}, \mathrm{CHR}$ and $\mathrm{BbF}$ were estimated as $\mathrm{BaP}$ equivalent concentrations $\left(\mathrm{TEQ}_{\mathrm{BaP}}\right)$ by multiplying each PAH concentration with its TEF. TEFs of BaA, CHR and BbF were 0.1, 0.01, and 0.1, respectively [11].

The daily intakes of 4 PAHs and $\mathrm{TEQ}_{\mathrm{BaP}}$ were calculated by using Eq. (1) [29].
In Eq. (2), $\mathrm{MOE}$ is calculated by dividing $\mathrm{BMDL}_{10}$ value by the estimated daily exposure, and $\mathrm{BMDL}_{10}$ value was set by the dose-response analysis for tumor type. $\mathrm{BMDL}_{10}$ for $\mathrm{BaP}$ and the sum of 4 PAHs ranged from 0.07 to $0.20 \mathrm{mg} \mathrm{kg}^{-1}$ b.w. day ${ }^{-1}$ and from 0.34 to $0.93 \mathrm{mg} \mathrm{kg}^{-1}$ b.w. day $^{-1}$ based on total tumour-bearing animals, respectively. Therefore, 0.07 and $0.34 \mathrm{mg} \mathrm{kg}^{-1}$ b.w. day ${ }^{-1}$

Daily exposure $\left(\frac{\mathrm{ng}}{\mathrm{kg} \text { b.w.day }}\right)=\frac{\text { concentration of } \mathrm{PAHs}\left(\text { or } \mathrm{TEQ}_{\mathrm{BaP}}\right)\left(\frac{\mathrm{ng}}{\mathrm{g}}\right) \times \text { daily edible oil intake }\left(\frac{\mathrm{g}}{\text { day }}\right)}{\text { body weight }(\mathrm{kg})}$

To characterize a risk of PAHs, MOE was estimated by using Eq. (2). The MOE is used for assessing the risk of substances which does not show a threshold in the dose-response curve because of their genotoxic and carcinogenic properties. Exposure of it should be minimized according to "As Low As Reasonably Achievable (ALARA)" principle. However, Risk manager cannot get any information from ALARA which degree they should reduce which substances. The MOE could be one of the suitable approaches for the risk managers to set a priority list by comparing an appropriate reference point with human intake. The MOE of 10,000 or high in general would be interpreted as low concern to public health [3]. were conservatively adopted for $\mathrm{BMDL}_{10}$ of the $\mathrm{BaP}$ and the 4 PAHs [3].

\section{Results and discussion}

\section{Quality control}

The specificity of the method was guaranteed by comparing retention times with reference materials in blank samples and monitoring fragment ions for each target compound. The calibration plots based on the linear regression analysis revealed good linear relationships between peak area and concentrations over the ranges $1-500 \mu \mathrm{g} \mathrm{L}^{-1}$ with correlation coefficients over 0.99 . The LOD and LOQ ranged from 0.02 to $0.13 \mathrm{ng} \mathrm{g}^{-1}$ and

$$
\text { Margin of Exposure }=\frac{\operatorname{BMDL}_{10}\left(\frac{\mathrm{ng}}{\mathrm{kg} \text { b.w.day }}\right)}{\text { The estimated daily exposure }\left(\frac{\mathrm{ng}}{\mathrm{kg} \text { b.w.day }}\right)}
$$




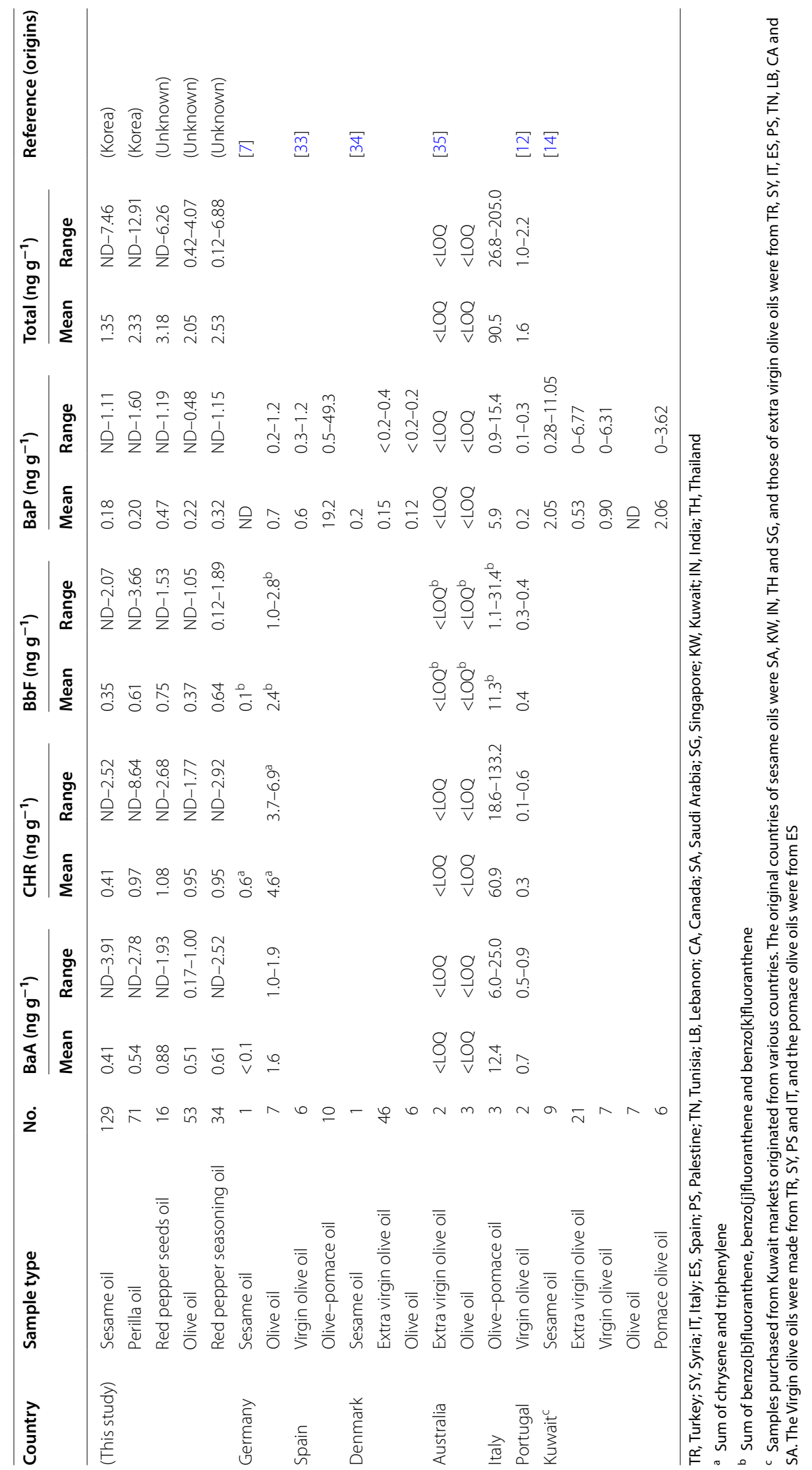




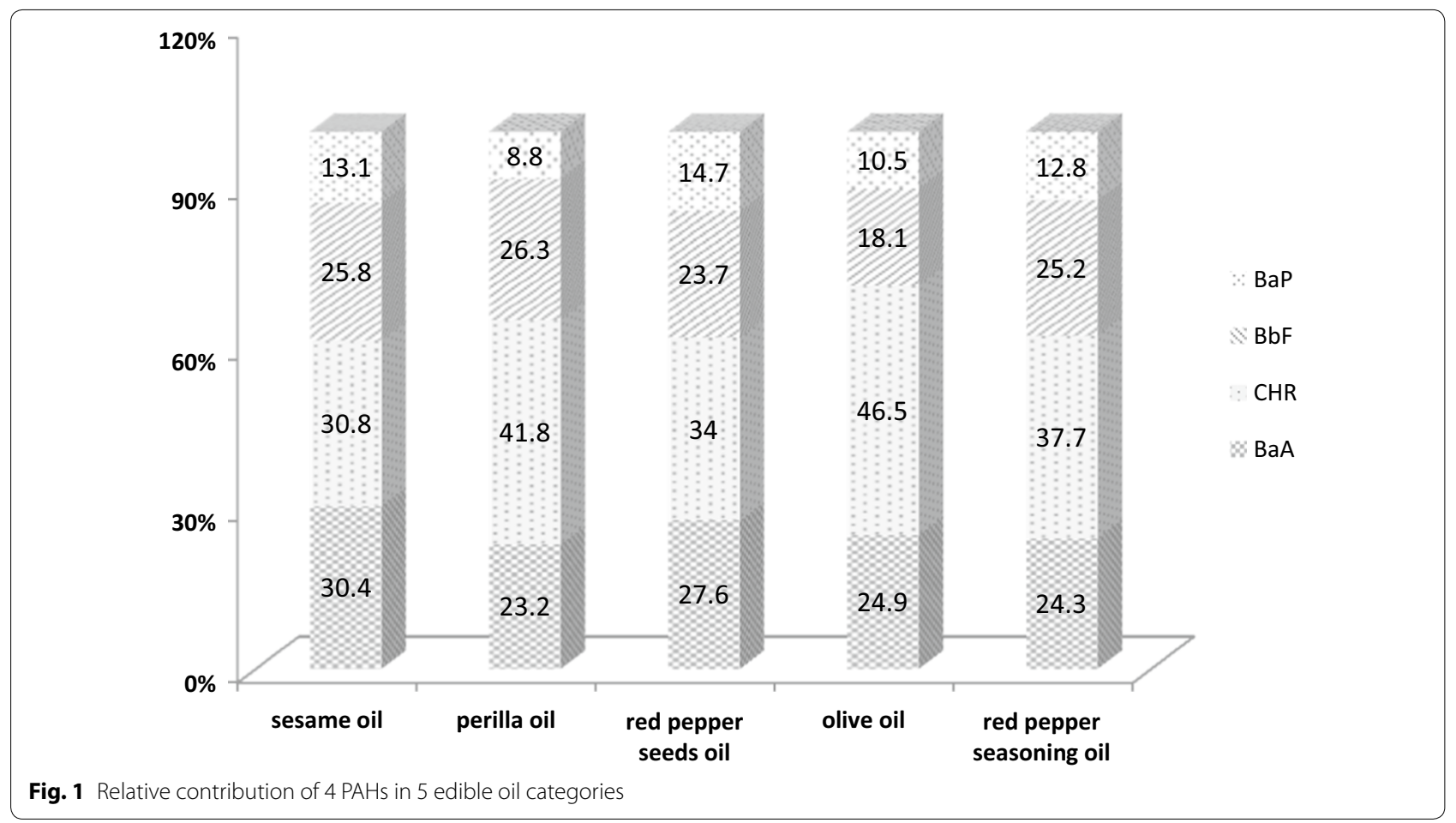

from 0.06 to $0.44 \mathrm{ng} \mathrm{g}^{-1}$ at four types of oil samples, respectively. The relative recoveries of 4 PAHs were from 70.7 to $110.4 \%$ at $2 \mathrm{ng} \mathrm{g}^{-1}$ and from 79.9 to $112.6 \%$ at $10 \mathrm{ng} \mathrm{g}^{-1}$. The RSD ${ }^{\mathrm{r}}$ for repeatability at a level of $2 \mathrm{ng} \mathrm{g}^{-1}$ were from 0.3 to $6.9 \%$, and from 1.4 to $8.8 \%$ at a level of $10 \mathrm{ng} \mathrm{g}^{-1}$. The $\mathrm{RSD}^{\mathrm{R}}$ for reproducibility was from 2.1 to $17.2 \%$ at a level of $2 \mathrm{ng} \mathrm{g}^{-1}$ and from 0.9 to $12.7 \%$ at a level of $10 \mathrm{ng} \mathrm{g}^{-1}$. All values of performances are shown in Table 1, and they are satisfying the criteria proposed by Association of Official Agricultural Chemists (AOAC) (Table 1) [30].

\section{Concentrations of PAHs in edible oil samples}

Table 2 shows means and ranges for $\mathrm{BaA}, \mathrm{CHR}, \mathrm{BbF}, \mathrm{BaP}$ and the sum of PAHs from edible oils analyzed in this study. A value below the LOQ was assigned to ND (not detected). The perilla oils and sesame oils were highly contaminated with PAHs. A maximum limit value of $2 \mathrm{ng} \mathrm{g}^{-1}$ for BaP was established in edible oils in Korea and EU [4]. The mean concentration of PAHs in 129 sesame oil samples analyzed was $0.41 \mathrm{ng} \mathrm{g}^{-1}$ for $\mathrm{BaA}$, $0.41 \mathrm{ng} \mathrm{g}^{-1}$ for CHR, $0.35 \mathrm{ng} \mathrm{g}^{-1}$ for BbF, $0.18 \mathrm{ng} \mathrm{g}^{-1}$ for $\mathrm{BaP}$ and $1.35 \mathrm{ng} \mathrm{g}^{-1}$ for the sum of 4 PAHs, respectively. The contents of $\mathrm{BaP}$ in sesame oils were lower than maximum limit. The mean concentration of $\mathrm{BaA}$ (0.54 $\mathrm{ng} \mathrm{ng}^{-1}$ ), CHR (0.97 ng ng $\left.{ }^{-1}\right), \mathrm{BbF}\left(0.61 \mathrm{ng} \mathrm{ng}^{-1}\right.$ ) and $\mathrm{BaP}\left(0.20 \mathrm{ng} \mathrm{ng}^{-1}\right)$ for 71 perilla oil samples were analyzed and $\mathrm{BaP}$ were contaminated lower than the established maximum limit. Table 2 shows PAHs content of edible oils in other countries. Red pepper seeds oil contained the highest 4 PAHs content in edible oils in Korea. However, there were no researches to determine PAHs content in red pepper seed oils in other countries. Meanwhile, PAHs contents in sesame oil and olive oil in Korea were similar with or lower than those in other countries. The relative contributions of each of the 4 PAHs to the total content of 4 PAHs in five edible oil categories were shown in Fig. 1. CHR had the highest average contributions of $30.8-46.5 \%$ in edible oils, and $\mathrm{BaA}, \mathrm{BbF}$ and $\mathrm{BaP}$ had the average contributions of 23.2$30.4 \%, 18.1-26.3 \%$ and $8.8-14.7 \%$, respectively. Figure 2 shows the correlation of $\mathrm{BaP}$ and 4 PAHs in 5 edible oils. $\mathrm{BaP}$ has strong correlations with 4 PAHs in sesame oil, red pepper seasoning oil and red pepper seeds oil with correlation coefficients higher than 0.8 . BaP has also correlations with 4 PAHs in other edible oils. However, some sesame oils and perilla oils contain 4 PAHs when BaP is not detected. Therefore, $\mathrm{BaP}$ is not good to represent 4 PAHs, even though BaP has correlations with 4 PAHs. Alomirah also figured out that Bap was not detected in some olive oils while eight genetoxic PAHs were detected and $\mathrm{BaP}$ is not good as the indicator for PAHs [14].

\section{Consumptions of edible oils}

The consumption of sesame oils, perilla oils and olive oils were reported in KNHANES, whereas the consumptions 


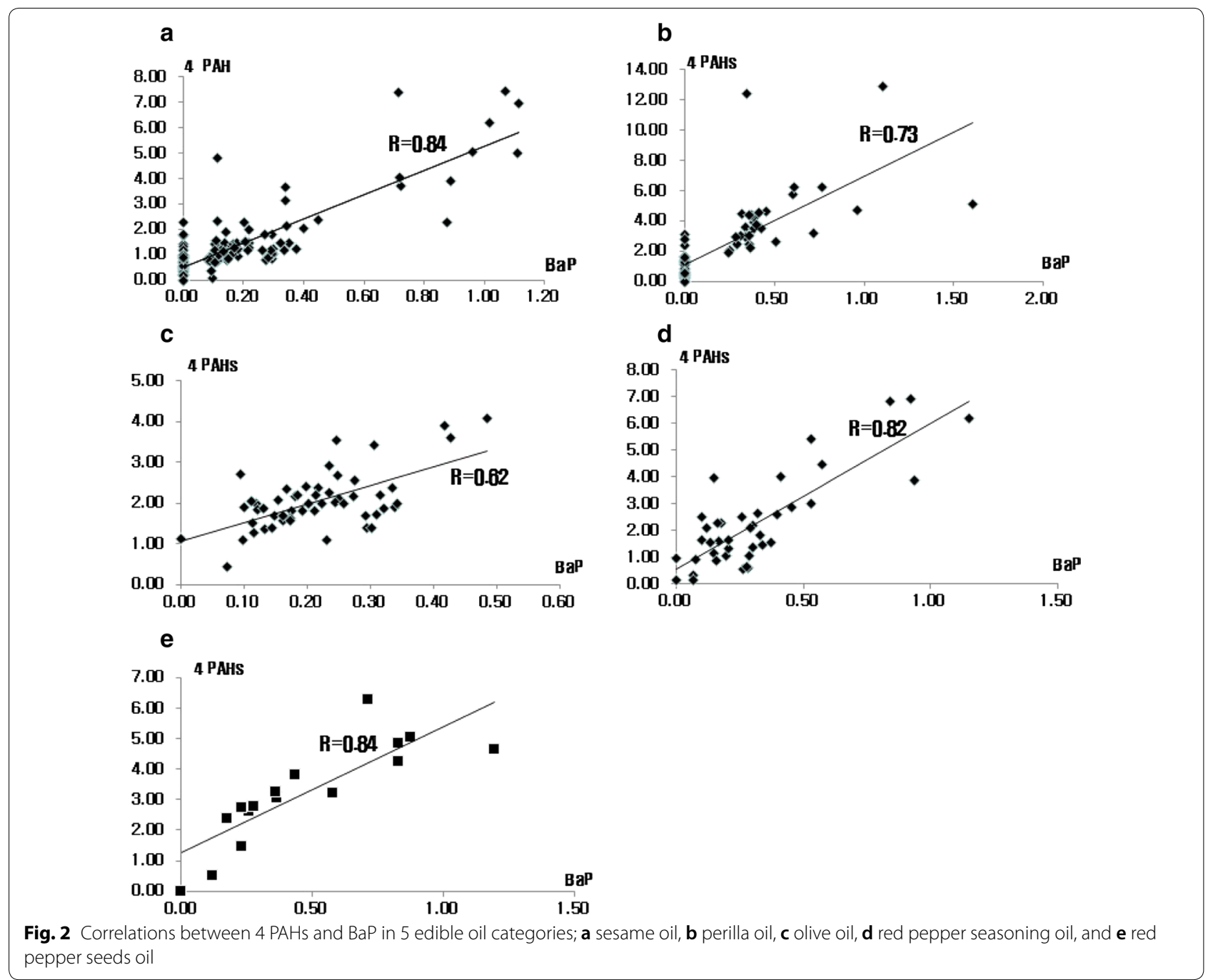

Table 3 Consumption amounts of edible oils and estimated concentrations of each 4 PAH according to the proportion of not-detected samples

\begin{tabular}{|c|c|c|c|c|c|c|c|c|c|c|}
\hline \multirow[t]{3}{*}{ Type } & \multicolumn{4}{|c|}{ Daily intake $\left(\mathrm{g} \mathrm{day}^{-1}\right)$} & \multicolumn{6}{|c|}{ Estimated concentration $\left(\mathrm{ng} \mathrm{g}^{-1}\right)$} \\
\hline & \multicolumn{2}{|c|}{ Total population } & \multicolumn{2}{|c|}{ Consumer only } & \multirow[t]{2}{*}{$\mathrm{BaA}$} & \multirow[t]{2}{*}{ CHR } & \multirow[t]{2}{*}{$\mathrm{BbF}$} & \multirow[t]{2}{*}{$\mathrm{BaP}$} & \multirow[t]{2}{*}{$4 \mathrm{PAHs}^{\mathrm{b}}(\mathrm{sum})$} & \multirow[t]{2}{*}{$\mathrm{TEQ}_{\mathrm{BaP}}{ }^{\mathrm{c}}(\mathrm{TEFs})$} \\
\hline & Mean & $\mathrm{P} 95^{\mathrm{a}}$ & Mean & P95 & & & & & & \\
\hline Sesame oil & 1.60 & 6.52 & 2.30 & 7.60 & 0.43 & 0.43 & 0.36 & 0.19 & 1.41 & 0.27 \\
\hline Perilla oil & 0.14 & 0.51 & 1.70 & 6.10 & 0.58 & 0.99 & 0.64 & 0.26 & 2.47 & 0.39 \\
\hline Red pepper seeds oil & 0.01 & 0 & 2.00 & 5.00 & 0.90 & 1.12 & 0.76 & 0.47 & 3.23 & 0.30 \\
\hline Olive oil & 0.10 & 0 & 2.50 & 9.80 & 0.51 & 0.96 & 0.37 & 0.22 & 2.05 & 0.11 \\
\hline Red pepper seasoning oil & 0.01 & 0 & 2.00 & 5.00 & 0.65 & 0.98 & 0.64 & 0.33 & 2.59 & 0.46 \\
\hline
\end{tabular}

${ }^{a}$ Daily intake of edible oils at the 95 th percentile

b The Sum of BaA, CHR, BbF and BaP contents

c The estimated equivalent concentrations of BaP calculated by TEFs of BaA, CHR and BbF 


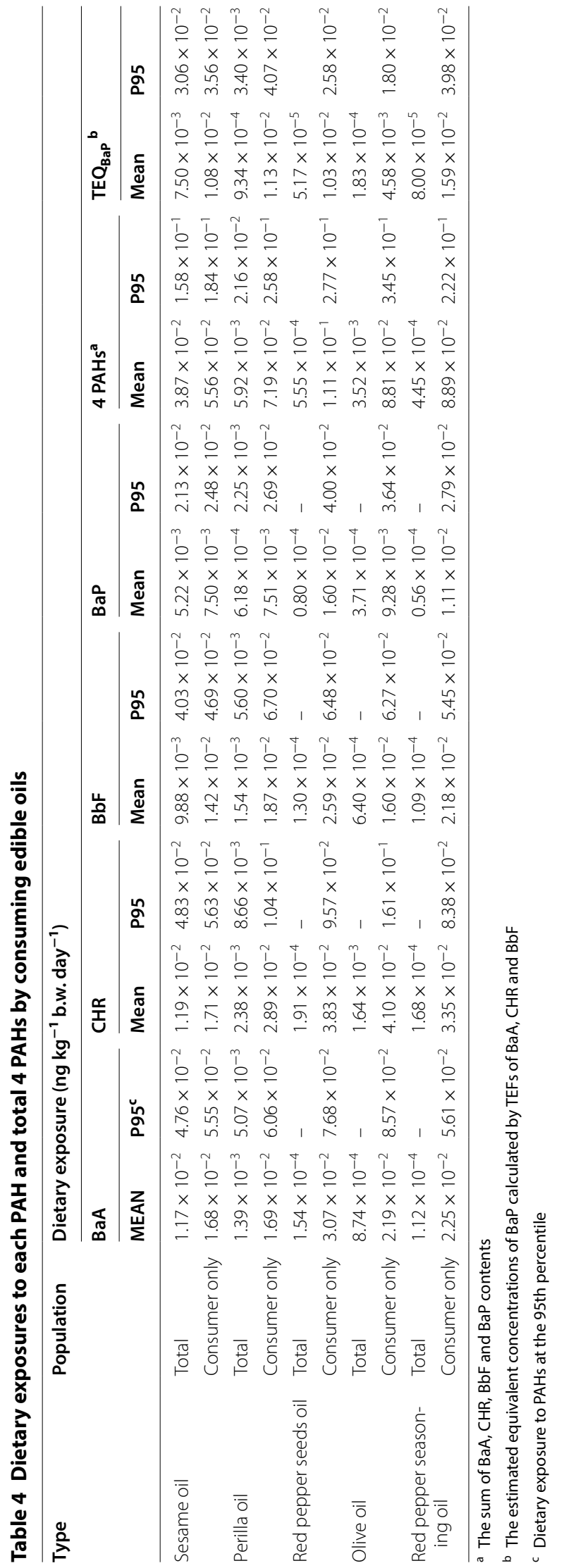


Table 5 MOEs of total 4PAHs by sum of each PAH and TEQ ${ }_{\mathrm{BaP}}$ as BaP concentration estimated by TEFs

\begin{tabular}{|c|c|c|c|c|c|c|c|c|}
\hline \multirow[t]{4}{*}{ Type } & \multicolumn{8}{|l|}{ MOEs } \\
\hline & \multicolumn{4}{|c|}{ Total population } & \multicolumn{4}{|c|}{ Consumer only } \\
\hline & \multicolumn{2}{|l|}{$4 \mathrm{PAHs}^{\mathrm{a}}$} & \multicolumn{2}{|l|}{$\mathrm{TEQ}_{\mathrm{BaP}} \mathbf{b}$} & \multicolumn{2}{|l|}{4 PAHs } & \multicolumn{2}{|l|}{$\mathrm{TEQ}_{\mathrm{BaP}}$} \\
\hline & Mean & P95 & Mean & P95 & Mean & P95 & Mean & P95 \\
\hline Sesame oil & $8,785,530$ & $2,151,899$ & $9,333,333$ & $2,287,582$ & $6,115,108$ & $1,847,826$ & $6,481,481$ & $1,966,292$ \\
\hline Perilla oil & $57,432,432$ & $15,740,741$ & $74,916,474$ & $20,588,235$ & $4,728,790$ & $1,317,829$ & $6,194,690$ & $1,719,902$ \\
\hline Red pepper seeds oil & $613,076,828$ & - & $1,346,153,846$ & - & $3,063,063$ & $1,227,437$ & $6,796,117$ & $2,713,178$ \\
\hline Olive oil & $96,590,909$ & - & $381,758,653$ & - & $3,859,251$ & 985,507 & $15,283,843$ & $3,888,889$ \\
\hline Red pepper seasoning oil & $764,501,697$ & - & $879,715,456$ & - & $3,824,522$ & $1,531,532$ & $4,402,516$ & $1,758,794$ \\
\hline Total & $6,919,104$ & $1,893,096$ & $8,000,634$ & $2,058,824$ & 818,291 & 264,386 & $1,323,752$ & 437,774 \\
\hline
\end{tabular}

a The sum of $\mathrm{BaA}, \mathrm{CHR}, \mathrm{BbF}$ and $\mathrm{BaP}$ contents

b The estimated equivalent concentrations of $\mathrm{BaP}$ calculated by TEFs of $\mathrm{BaA}, \mathrm{CHR}$ and $\mathrm{BbF}$

c Dietary exposure to $\mathrm{PAHs}$ at the 95 th percentile

of red pepper seeds oils and red pepper seasoning oils did not appear in KNHANES. Therefore, the amounts of red pepper seeds oils and red pepper seasoning oils intake were substituted by the consumption data of hot sauces. The mean daily intake and the consumption at the 95th percentile of edible oils for total population and consumers are shown in Table 3. The zero consumption data at 95th percentile means that the Korean consumer intake edible oils a lot whenever they eat, but not too frequently.

\section{Exposure assessment}

The proportions of samples contaminated with PAHs below the LOD were below $60 \%$ and the values below the LOD was replaced to half of LOD. The estimated mean concentrations of 4 PAHs in edible oils were from 0.19 to $1.12 \mathrm{ng} \mathrm{g}^{-1}$ (Table 2). The total contents of 4 PAHs and the total $\mathrm{BaP}$ equivalent values were from 1.41 to 3.23 and from 0.11 to 0.46 (Table 3). The average bodyweight of Korean was $58.3 \mathrm{~kg}$ [22-24]. Table 4 shows the average and 95th percentile daily intakes of $4 \mathrm{PAHs}$ for total populations and consumers. The daily exposures to high consumers in the 95th percentile were from three times to five times greater than that of mean daily consumers. Furthermore, the mean and high exposures to total 4 PAHs for total populations and consumers only were shown in Table 4, and they were compared with the exposures to estimated equivalent BaP. Korean people were the most highly exposed to PAHs from sesame oils among edible oils according to the estimations by both sum of each $\mathrm{PAH}$ and $\mathrm{TEQ}_{\mathrm{BaP}}$. This highest intake of PAHs by consumption of sesame oils arises because Korean people consume sesame oil over 10 times more than other edible oils although the sesame oils are not highly contaminated with PAHs compared to others. Meanwhile, Korean consuming edible oils was exposed to PAHs mostly by olive oil due to the highest contamination of PAHs. In Brazil, people exposure to 4 PAHs of $7.3 \mathrm{ng} \mathrm{kg}^{-1}$ b.w. day ${ }^{-1}$ via edible oils (soybean oils) [31], and in Australia, People consume canola oil of $0.3 \mathrm{~g}^{-1 a y}{ }^{-1}$ and it contains BaA of below $0.06 \mathrm{ng} \mathrm{g}^{-1}$, Chr of below $0.1 \mathrm{ng} \mathrm{g}^{-1}$, BaP of below $0.08 \mathrm{ng} \mathrm{g}^{-1}$. People in Australia exposure to $\mathrm{BaA}$ of $0.018 \mathrm{ng} \mathrm{kg}^{-1} \mathrm{day}^{-1}$, Chr of $0.03 \mathrm{ng} \mathrm{kg}^{-1} \mathrm{day}^{-1}$ and BaP of $0.024 \mathrm{ng} \mathrm{kg}^{-1} \mathrm{day}^{-1}$ at most [32]. In Europe, the exposure to $\mathrm{BaP}$ and 4 PAHs via fats (vegetable and animal) are $26 \mathrm{ng} \mathrm{day}^{-1}$ and $177 \mathrm{ng} \mathrm{day}^{-1}$ [3]. Korean is not highly exposed to PAHs by eating edible oils comparing to other countries' people.

\section{Risk characterisation}

The risk of PAHs by dietary intake of edible oils was characterised by calculating MOEs (Table 5). With regard to average consumption, the MOE of 4 PAHs for total population was $6,919,104$ and that of consumers only was 818,291 . In the case of high consumption in the 95th percentile, the MOEs were 1,893,096 and 264,386 for total population and consumers, respectively. All MOEs were over $1.0 \times 10^{4}$ and it was found that the risk of 4 PAHs in edible oils is "low concern from a public health point of view" [3]. According to the French total diet study, edible oils are the main contributors (16.2\%) to PAHs exposure via foods [33]. If Korean people are exposed to PAHs by edible oils with contribution of about $20 \%$, MOEs will be between 66,096 and 1,729776. Therefore, exposure to PAHs by consuming food does not still represent a food safety issue to Korean people.

Furthermore, the MOEs of the estimated equivalent $\mathrm{BaP}$ calculated by TEFs of other 3 PAHs were from $2,058,824$ to $8,000,634$ for total population and 437,774 to $1,323,752$ for consumers only. These MOEs are from 1.1 to 1.7 times higher than those of total of 4 PAHs. 
Therefore the risk of 4 PAHs estimated by the TEFs can be over-estimated comparing to the risk of total 4 PAHs. Many studies assessing the risk of PAHs by TEFs need to be re-assess the risk of PAHs by using total PAHs concentration and toxicological value from mixture of PAHs.

\section{Acknowledgements}

This research was supported by a Grant (13161MFDS932) from Ministry of Food and Drug Safety in 2013.

\section{Authors' contributions}

JG validated analytical method and analysed samples and JH statistically analysed data. $\mathrm{HJ}$ interpreted effects of food processing on contents of PAHs. All authors read and approved the final manuscript.

\section{Funding}

This research was supported by a Grant (13161MFDS932) from Ministry of Food and Drug.

\section{Availability of data and materials}

All data analysed during this study are included in this published article.

\section{Competing interests}

The authors declare that they have no competing interests.

Received: 10 June 2019 Accepted: 17 August 2019

Published online: 03 October 2019

\section{References}

1. IARC (2010) Monographs on the evaluation of carcinogenic risk to humans, overall evaluations of carcinogenicity. IARC Monogr Eval Carcinogen Risks Hum Suppl 92:33-814

2. Zelinkova Z, Wenzi T (2015) The occurrence of 16 EPA PAHs in food-a review. Polycyclic Aromatic Compd 1:1-37

3. European Food Safety Authority (EFSA) (2008) Polycyclic aromatic hydrocarbons in food. Scientific opinion of the panel on contaminants in the food chain. EFSA J 724:1-114

4. European Commission (EC) (2011) Commission regulation (EC) No. 835/2011 of 19 August 2011 amending regulation (EC) No. 1881/2006 as regards maximum levels for polycyclic aromatic hydrocarbons in foodstuffs. In: Official Journal of the European Union. European Commission, Brussels

5. Lee JG, Kim SY, Moon JS, Kim SH, Kang DH, Yoon HJ (2016) Effects of grilling procedures on levels of polycyclic aromatic hydrocarbons in grilled meats. Food Chem 199:632-638

6. Simko P, Khunova V, Simon P, Hruba M (1995) Kinetics of sunflower oil contamination with polycyclic aromatic hydrocarbons from contaminated recycled low density polyethylene film. Int J Food Sci Technol 30:807-812

7. Speer K, Steeg E, Horstmann P, Ku“hn T, Montag A (1990) Determination and distribution of polycyclic aromatic hydrocarbons in native vegetable oils, smoked fish products, mussels and oysters, and bream from the river Elbe. J High Resolut Chromatogr 13:104-111

8. Lee J, Lim T, Kim S, Kang D, Yoon H (2018) Determination and risk characterization of polycyclic aromatic hydrocarbons of tea by using the Marin of Exposre (MOE) approach. Food Sci Biotechnol 27(6):1843-1856

9. Balenovic J, Petrovic I, Perkovac M (1995) Determination of polycyclic aromatic hydrocarbons in vegetable oils. In: Proceedings of the European Conference on Food Chemistry. Vienna, European Food Chemistry, pp 275-281

10. Moret S, Dudine A, Conte LS (2000) Processing effects on the polycyclic aromatic hydrocarbon content of grapeseed oil. J Am Oil Chem Soc 77:1289-1292

11. Moret S, Purcaro G, Conte LS (2005) Polycyclic aromatic hydrocarbons in vegetable oils from canned foods. Eur J Lipid Sci Technol 107(7-8):488-496
12. Teixeira VH, Casal S, Oliveira MBPP (2007) PAHs content in sunflower, soybean and virgin olive oils: evaluation in commercial samples and during refining process. Food Chem 104:106-112

13. Starvic B, Klassen R (1994) Dietary effects on the uptake of benzo[a] pyrene. Food Chem Toxicol 32:727-734

14. Alomirah H, Al-Zenki S, Husain A, Sawaya W, Ahmed N, Gevao B, Kannan K (2010) Benzo(a)pyrene and total polycyclic aromatic hydrocarbons (PAHs) levels in vegetable oils and fats do not reflect the occurrence of the eight genotoxic PAHs. Food Addit Contam 27(6):869-878

15. Nisbet ICT, Lagoy PK (1992) Toxic equivalency factors(TEFs) for polycyclic aromatic hydrocarbons (PAHs). Regul Toxicol Pharmacol 16:290-300

16. Jiang D, Xin C, Li W, Chen J, Li F, Chu Z, Xiao P, Shao L (2015) Quantitative analysis and heatlh risk assessment of polycyclic aromatic hydrocarbons in edible oils marketed in Shandong of China. Food Chem Toxicol 83:61-67

17. Zhao Z, Zhang L, Cai Y, Chem Y (2014) Distribution of polycyclic aromatic hydrocarbon $(\mathrm{PAH})$ residues in several tissues of edible fishes from the largest freshwater lake in China, Poyang Lake, and associated human health risk assessment. Ecotoxicol Environ Saf 104:323-331

18. Benford D, Bolger PM, Carthew P, Coulet M, DiNovi M, Leblanc JC, Renwick AG, Setzer W, Schlatter J, Smith B, Slob W, Wiliams G, Wildemann T (2010) Application of the Margin of Exposure (MOE) approach to substances in food that are genotoxic and carcinogenic. Food Chem Toxicol 48(1):S2-S24

19. Join FAO/WHO Expert Committee on Food Additives (JECFA) (2005) Summary and conclusions of the sixty-fourth meeting of the Joint FAO/WHO expert Committee on Food Additives, WHO Food Additives Series No. 30. World Health Organization (WHO), Geneva

20. Obrien J, Renwick AG, Constable A, Dybing E, Müller DJG, Schlatter J, Slob W, Tueting W, van Benthem V, Williams GM, Wolfreys A (2006) Approaches to the risk assessment of genotoxic carcinogens in food: a critical appraisal. Food Chem Toxicol 44(10):1613-1635

21. Lee JG, Park SK, Yoon HJ, Kang DH, Kim MH (2016) Exposure assessment and risk characterisation of ethyl carbamate from Korean traditional fermented rice wine, Takju and Yakju. Food Addit Contam A. 33(2):207-214

22. CDC (2008) Korea Centers for Disease Control and Prevention guideline for the evaluation of the fourth Korea national health \& nutrition examination survey. Korea Centers for Disease Control and Prevention, Osong

23. CDC (2009) Korea Centers for Disease Control and Prevention guideline for the evaluation of the fourth Korea national health \& nutrition examination survey. Korea Centers for Disease Control and Prevention, Osong

24. CDC (2010) Korea Centers for Disease Control and Prevention guideline for the evaluation of the fourth Korea national health \& nutrition examination survey. Korea Centers for Disease Control and Prevention, Osong

25. Korean Ministry of Food and Drug Safety (MFDS) (2013) Korean Food Code. Osong, Ministry Food and Drug Safety. https://www.mfds. go.kr/eng/brd/m_15/view.do?seq $=69982 \& \mathrm{srchFr}=\& \mathrm{srchTo}=\& \mathrm{srchW}$ ord $=\&$ srchTp $=\& i t m \_s e q \_1=0 \& i t m \_s e q \_2=0 \&$ multi_itm_seq $=0 \&$ compa ny_cd $=\&$ company_nm $=\&$ page $=3$

26. Eurachem Working Group (1998) The Fitness for purpose of analytical methods, a laboratory guide to method validation and related topics. In: Eurachem Guide

27. Kweon S, Kim Y, Jang M, Kim Y, Kim K, Choi S, Chun C, Khang Y, Oh K (2014) Data resource profile: the Korea National Health and Nutrition Examination Survey (KNHANES). Int J Epidemiol 43:69-77

28. Global Environment Monitoring System-Food contamination Monitoring and Assessment Program (GEMS/Food)-EURO (1995) GEMS/Food-EURO Second Workshop on Reliable evaluation of low level contamination of food; 1995 May 26-27. Kulmbach, Germnay

29. Yoon E, Park K, Lee H, Yang J, Lee C (2007) Estimation of excess cancer risk on time-weighted lifetime average daily intake of PAHs from food ingestion. Hum Ecol Risk Assess 13:669-680

30. Taverniers I, Loose MD, Bocksaele EV (2004) Trends in quality in the analytical laboratory. II. Anlytical method validation and quality assurance. Trends Anal Chem 23(8):535-552

31. Camargo MCR, Antoniolli PR, Vicente E, Tfouni SAV (2011) Polycyclic aromatic hydrocarbons in Brazilian commercial soybean oils and dietary exposure. Food Addit Contamin B. 4(2):152-159 
32. Food Standards Australia New Zealand (FSANZ) (2004) Survey of polycyclic aromatic hydrocarbons (PAH) in Australian Foods-dietary exposure assessment and risk characterization. http://www.foodstandards.gov.au/ science/surveillance/documents/PAH\%20Survey\%20for\%20website.pdf

33. Veyrand B, Sirot V, Durand S, Pollono C, Marchand P, Dervilly-Pinel G, Tard A, Leblanc JC, Bizec BL (2013) Human dietary exposure to polycyclic aromatic hydrocarbons: results of the second French total diet study. Environ Int 54:11-17

34. Fromberg A, Hojgard A, Deudalhl-Olesen L (2007) Analysis of polycylic aromatic hydrocarbons in vegetable oils combining gel permeation chromatorgraphy with soild-phase extraction clean-up. Food Addit Contam 24(7):758-767
35. Pucaro G, Morrison P, Moret S, Conte LS, Marriott PJ (2007) Determination of polycyclic aromatic hydrocarbons in vegetable oils using solid-phase microextraction-comprehensive two-dimentional gas chromatography coupled with time-of flight mass spectrometry. J Chromatogr A 1161:284-291

\section{Publisher's Note}

Springer Nature remains neutral with regard to jurisdictional claims in published maps and institutional affiliations.

\section{Submit your manuscript to a SpringerOpen ${ }^{\circ}$ journal and benefit from:}

- Convenient online submission

- Rigorous peer review

- Open access: articles freely available online

- High visibility within the field

- Retaining the copyright to your article

Submit your next manuscript at $\boldsymbol{\nabla}$ springeropen.com 